\title{
The Remarkable Plasticity of Macrophages: A Chance to Fight Cancer
}

\author{
Nadège Bercovici ${ }^{1,2,3}$, Marion V. Guérin ${ }^{1,2,3}$, Alain Trautmann ${ }^{1,2,3}$ and \\ Emmanuel Donnadieu ${ }^{1,2,3 *}$
}

${ }^{1}$ INSERM, U1016, Institut Cochin, Paris, France, ${ }^{2}$ CNRS, UMR8104, Paris, France, ${ }^{3}$ Université Paris Descartes, Sorbonne Paris Cité, Paris, France

It is well established that tumor-associated macrophages (TAM) found in most advanced tumors have a pro-tumoral role. In this context, TAM limit the activity of tumor-infiltrating lymphocytes (TIL), and a number of mechanisms have been described including a trapping in the stroma, impeding TIL to reach malignant cells. Based on these results, a number of therapeutic approaches have been designed to deplete TAM. However, during tumor regression induced by immunotherapeutic treatments, recent studies revealed that TAM can switch from pro-tumoral to anti-tumoral and actively cooperate with TIL. Here, we will review the two faces of TAM in their interaction with TIL. We will summarize how

OPEN ACCESS

Edited by:

Maija Hollmén,

University of Turku, Finland

Reviewed by:

Paola Allavena

Milan University, Italy

Reno Debets,

Erasmus University

Rotterdam, Netherlands

*Correspondence:

Emmanuel Donnadieu

emmanuel.donnadieu@inserm.fr

Specialty section:

This article was submitted to Cancer Immunity and Immunotherapy, a section of the journal

Frontiers in Immunology

Received: 18 March 2019 Accepted: 24 June 2019 Published: 12 July 2019

Citation:

Bercovici N, Guérin MV, Trautmann A and Donnadieu E (2019) The

Remarkable Plasticity of Macrophages: A Chance to Fight Cancer. Front. Immunol. 10:1563. doi: 10.3389/fimmu.2019.01563 they can inhibit $T$ cell activities in growing tumors, and how they may also, together with $T$ cells, successfully contribute to tumor eradication after an appropriate stimulation. Finally, we will discuss current promising therapies combining TAM reprogramming with T cell-based immunotherapy.

Keywords: cancer, macrophages, T cells, immunotherapy, migration, inflammation

\section{INTRODUCTION}

Macrophages are amongst the most versatile cells in the body. Resident macrophages are abundant in all tissues where, like microglia in the brain or Kuppfer cells in the liver, these "pro-tissular macrophages" contribute to optimize the functioning of the tissue in which they are, by maintaining it clean and preventing an unnecessary inflammation (1). Besides, following an appropriate stimulation, e.g., following an infection, macrophages may be key contributors to immune responses (2). They participate to a variety of functions, primarily as effector cells to eliminate the invading bodies but also to drive an acute inflammation, to promote the recruitment of other immune cells as well as to present antigens to $\mathrm{T}$ cells. The switch from the pro-tissular, anti-inflammatory state to the pro-immune, inflammatory one, may take place within a few minutes. This is what happens to subcapsular macrophages when they detect the arrival of pathogens in the lymph node subcapsular sinus (3). This switch may take hours or days, when it involves the recruitment of blood monocytes, followed by their appropriate differentiation in the tissue. Even though the distinction between pro-tissular and pro-immune macrophages shares similarities with the M2/M1 distinction, we favor the idea that the most important difference between these two macrophage subtypes is functional rather than phenotypic.

In advanced tumors, macrophages favor tumor growth and are associated with a bad outcome in most cancers. Therefore, tumor-associated macrophages (TAM) are usually considered as simply "pro-tumoral". This has not always been the case. In the 1990s, a potential role of macrophages 
for cancer treatment has been a popular idea and this concept has begun to emerge. Indeed, in sensitized tumors, macrophages may be anti-tumoral, with the modulation of some gene expression (4).

We will summarize here some specific consequences of the functioning of macrophages in progressing tumors, in which their dominant role is pro-tumoral and immunosuppressive. In particular, we will focus on the mechanisms by which TAM limit TIL from reaching tumor cells. We will continue by considering how one can favor the switch of TAM to pro-immune cells exerting an anti-tumoral action. For these two TAM faces, our focus will be on positive or negative interactions between TAM and TIL, as summarized in the Figure 1.

\section{TAM INHIBIT T CELL ACTIVITIES IN PROGRESSING TUMORS}

TAM can promote tumor growth by a variety of mechanisms that include tumor cell proliferation, metastasis, angiogenesis and inhibition of $\mathrm{T}$ cell anti-tumoral activities. A considerable number of excellent reviews have been published on the various ways in which TAM contribute to tumor growth [for instance see (5)]. Yet, the mechanisms by which TAM negatively control T cells are not completely understood and we would like to focus on those related to intratumoral $\mathrm{T}$ cell migration.

\section{TAM Impair T Cell Migration Within Tumors}

Our team has recently shown that, in untreated progressing tumors, TAM have a detrimental impact on TIL ability to migrate within tumors and contact malignant cells (6). By using an experimental system based on thick slices made from fresh tumor biopsies combined with fluorescent imaging microscopy, we evidenced the presence of stable conjugates formed between TAM and CD3 T cells in the stroma of human lung tumors as illustrated in the Figure 2A. If such interactions do not result in $\mathrm{T}$ cell activation, macrophages could contribute to sequestering lymphocytes away from tumor cells (6). Remarkably, in mouse mammary tumor models we found that the depletion of TAM with pexidartinib, an inhibitor of the colony stimulating factor 1 receptor (CSF1R), increased the motility of TIL and their ability to reach tumor cells. This is consistent with data obtained in a mouse model of pancreatic carcinoma but with a CD8 T cell-macrophage trapping process that occurs outside the tumor (7). Whether a similar mechanism also affects CD4T cells is unknown for the moment. In murine lymph nodes, macrophages were shown to sequester $\gamma \delta \mathrm{T}$ cells unable to recirculate in the blood (8).

Altogether, these data suggest that TAM participate to the exclusion of TIL from the vicinity of cancer cells which

\footnotetext{
Abbreviations: CAF, carcinoma-associated fibroblasts; CAR, chimeric antigen receptor; CSF1R, colony stimulating factor 1 receptor; ECM, extracellular matrix; HDAC, histone deacetylase; IFN, interferon; PI3K, phosphatidylinositol 3-kinase; STING, stimulator of interferon genes; TAM, tumor-associated macrophages; TIL, tumor-infiltrating lymphocytes; TGF $\beta$, transforming growth factor beta.
}

is considered to be a major hurdle for $\mathrm{T}$ cell-based antitumor immunotherapy.

\section{Mechanisms Underlying Blockade of T Cell Migration by TAM}

The mechanisms by which TAM prevent CD8 T cells from reaching tumor cells is not known at the moment. We favor an adhesion process between both cell types triggered by an antigen recognition which by itself is insufficient to trigger full $\mathrm{T}$ cell activation. This would be in line with data showing antigen-dependent interactions between CD8 T cells and myeloid cells in a spontaneous mammary carcinoma murine model (9). However, the nature of the adhesion molecules involved in such cell-cell conjugates needs to be further investigated.

An effect of TAM on environmental factors controlling the motility of $\mathrm{T}$ cells cannot be ruled out. Studies performed over the last few years have provided evidence for a role of the structure of the tissue and the presence of chemokines in regulating the migration of $\mathrm{T}$ cells (10). By tracking $\mathrm{T}$ cells in fresh human lung tumor slices, we reported an important role of chemokines produced by tumor cells in the ability of $\mathrm{T}$ cells to infiltrate tumor islets (11). Such chemokines contribute to a low grade chronic inflammation. In mice harboring mammary tumors, we found that the depletion of TAM resulted in more inflammatory chemokines, such as CCL2 and CXCL10, which are likely to enhance the entry of $\mathrm{T}$ cells into the tumor and their intratumoral migration (6). The reason of an enhanced production of chemokines upon TAM depletion is not known for the moment. One possibility is that TAM could participate to the degradation and/or inactivation (e.g., nitration) of inflammatory chemokines, a process reported to occur in murine tumors (12).

A hallmark of advanced tumors is the development of a fibrosis characterized by an excessive accumulation of collagen I, likely to favor tumor progression and prevent antitumor $\mathrm{T}$ cell functions by limiting lymphocytes from migrating and contacting tumor cells, as we have previously demonstrated (13). Thus, a dense extracellular matrix (ECM) made by activated carcinoma-associated fibroblasts (CAF) might be responsible for the excluded $\mathrm{T}$ cell profile observed in various human carcinomas. The cells and elements that are susceptible to enhance collagen I production by CAF include macrophages. In many physiological situations like breast development, macrophages actively participate to the construction of the tissue $(14,15)$. In addition, the number of pro-tissular macrophages parallels the amount of tissue fibrosis in many human tumors. For example in colorectal tumors and in melanoma, a mesenchymal signature, associated with a bad outcomes and resistance of PD-1 therapy, are characterized by genes involved in extracellular matrix remodeling, angiogenesis, wound healing and TAM suggesting that pro-tissular macrophages and CAF are part of a similar environment (16-18). Evidence obtained in mouse models of colon cancer and pancreatic ductal adenocarcinoma indicates a role of TAM in ECM production within the tumor suggesting that TAM could indirectly inhibit 

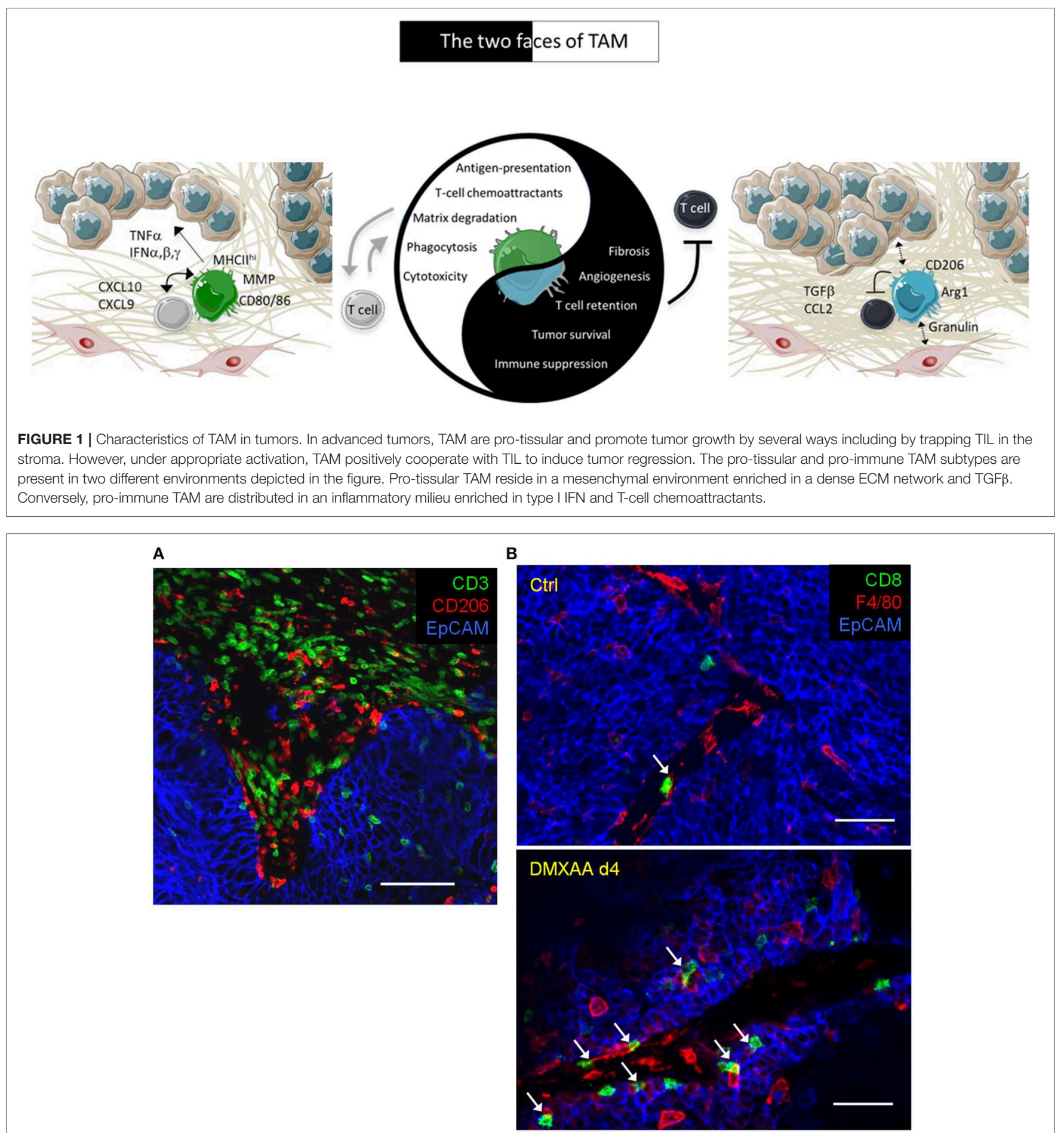

FIGURE 2 | Within tumors, T cells and macrophages are often in contact. (A) In a human lung tumor, numerous CD3T cells are potentially interacting with macrophages (stained by CD206). Bar, $100 \mu \mathrm{m}$. (B) Interactions between TIL and TAM in mammary carcinoma mouse tumors (MMTV-PyMT) before and after 4 days (4d) of treatment with the STING agonist DMXAA. Of note, the immunotherapeutic agent induces a massive recruitment of CD8 T cells and macrophages (stained by F4/80) with many contacts between both cell types. White arrows indicate TAM-T cells contacts. Bar $50 \mu \mathrm{m}$.

T cell migration through the construction of a dense stroma (19, 20). TAM can fine-tune fibrosis by depositing and/or remodeling the ECM (20) but indirect effects through cross-talks with
CAF are also envisioned (Figure 1). In that context, a recent study demonstrates that TAM activate CAF to produce excessive amount of the ECM, excluding T cells from tumor cells, through 
the secretion of granulin, a growth factor belonging to the epithelin family (21).

\section{Macrophage-Depletion Strategies May Potentiate Anti-tumor T-Cell Therapies}

The aforementioned studies demonstrating a negative impact of TAM on T cells fostered the development of strategies combining pro-tissular macrophage-depletion with approaches that boost $\mathrm{T}$ cells. In preclinical mouse tumor models, the depletion of TAM has been combined with T cell-based therapies, both antiPD-1 and adoptive $\mathrm{T}$ cell transfer, which results in enhanced efficacy of the immunotherapy treatment (22-26). For example, we have shown that a macrophage-depletion strategy through CSF1R inhibition, which by itself has a minor effect on the tumor growth, also improved the efficacy of an anti-PD-1 treatment (6).

Based on these results, several therapeutic applications to impair TAM recruitment or survival are either entering or have entered clinical trials (27). CSF1R inhibitors are currently being tested, the most advanced being the smallmolecule Pexidartinib (28). However, CSF1R inhibitors have shown very limited antitumor effects in patients as single agents, suggesting the need to combine these inhibitors with other approaches, including immune checkpoint inhibitors. Such combination strategies are ongoing in a number of solid malignancies (NCT02452424, NCT02713529). Macrophages also use the CCL2/CCR2 axis to enter into tumors. Thus, antiCCR2 approaches are being developed to reduce the number of immunosuppressive macrophages into solid malignancies (29). In addition, chemotherapeutic agents (e.g., gemcitabine, cyclophosphamide, trabectedin), although not specific to TAM, have been shown to deplete myeloid cells (30-32).

\section{TOWARD STRATEGIES FAVORING AN ANTI-TUMORAL ROLE OF TAM}

There is increasing evidence that an appropriate activation of macrophages, rather than their depletion, would drastically potentiate an anti-tumor immune response. Macrophages appropriately stimulated by TLR ligands or after abundant cell death, be it induced by radiotherapy, chemotherapy or other means, are key players of an acute inflammation, with numerous consequences. First, inflammatory macrophages release chemokines, leading to the recruitment of innate immune cells and $\mathrm{T}$ cells (33). Another major feature of acute inflammation is the activation of the tumor vasculature which controls $\mathrm{T}$ cell extravasation $(34,35)$. In addition, activated macrophages can attack and reduce the density of the intratumoral ECM (36), thus facilitating TIL mobility in the tumor microenvironment. Finally, macrophages are the most abundant cells in tumors, after tumor cells themselves, which constitute a major asset to propagate de novo inflammatory process in the tumor microenvironment. A careful analysis of the various TAM subsets infiltrating human tumors revealed in addition that a high density of anti-tumoral TAM correlated with a favorable prognosis (37).
Historically, various clinical trials were initiated, for instance with the injection of activated macrophages (38) or cytokines and microbial derived molecules (39-43) aiming at activating macrophages directly in vivo. Anti-tumoral effects of such macrophage activators have been reported, but such approaches have been globally disappointing. The conclusion to be drawn from this scientific period is that targeting only macrophages cannot induce a systematic tumor regression.

These provisional failures and the very fast increase of $\mathrm{T}$ cell knowledge led, in the following years, to an almost complete oversight of anti-tumoral capabilities of macrophages. However, recent advances in myeloid cell biology are putting macrophages back into play, as we will discuss.

\section{Inhibition of Pro-tumoral TAM Orientation}

The inhibition of molecules that contribute to a pro-tumoral TAM orientation represents an interesting strategy. Here we will focus on TGF $\beta$, PI3K $\gamma$, and some HDAC (histone deacetylases) which will nicely illustrate our point.

\section{TGF $\beta$ Inhibition}

The major effect of TGF $\beta$, in large tumors in particular, is to resolve inflammation, to facilitate wound healing and to contribute to immunosuppression. TGF $\beta$ does it in various ways. In tumors, TAM are both a source and a target of TGF $\beta$, which is involved in a positive feed-back loop for stabilizing the pro-tumoral TAM phenotype. In parallel, TGF $\beta$ promotes the activation of fibroblasts while it inhibits the expression of several molecules necessary for the cytotoxic activity of $\mathrm{T}$ cells. Therefore, this molecule appeared to be a central mediator in the TAM/CAF/TIL axis. In the literature on erythropoiesis or on fibrotic diseases, one can find that an anti-TGF $\beta$ treatment could be done, in principle, by reducing the concentration of circulating TGF $\beta$ with anti-TGF $\beta$ antibodies or with TGF $\beta$ ligand traps (44), or with pharmacological blockers of TGF $\beta$ signaling, such as SB431542 (45). Importantly for the activity of anti-tumor $\mathrm{T}$ cells, the combination of TGF $\beta$ blockade and anti-PDL1 has been shown to decrease the activity of fibroblasts and the density of ECM relieving the exclusion of $\mathrm{T}$ cells from malignant cells $(46,47)$. Another major effect of TGF $\beta$ is the inhibition of IFN $\beta$ signaling as we have recently shown in murine spontaneous tumors (48). Type I IFN are central in the initiation of T-cell responses and this finding could be of major importance for combined anti-tumor treatments, in which an anti-TGF $\beta$ would not be active on its own, but only for amplifying the potency of T cells. An anti-TGF $\beta$ treatment could modify the TAM phenotype and sensitivity to STING agonist within 3 days in this spontaneous tumor model (48).

\section{Class II HDAC Inhibition}

Class IIa HDAC, which includes HDAC4, act quite differently from other HDAC. A specific Class IIa HDAC inhibitor, which appears to have no effect on $\mathrm{T}$ cells, is able to induce an inflammatory state by promoting the infiltration of phagocytic and immunostimulatory $\mathrm{CD} 40^{+} \mathrm{TAM}$, resulting in an antitumoral action (49). Thus, specific inhibitors of class IIa HDAC might prove to be of great interest in combined anti-tumoral 
therapies. Note that, in different instances, TGF $\beta$ effects appear to be mediated by HDAC4 $(48,50,51)$. Thus, the two molecules may use common pathways to maintain an immunosuppressive, anti-inflammatory macrophage activity.

\section{PI3K $\gamma$ Inhibition}

PI $3 \mathrm{~K} \gamma$ is a PI3K activated by chemokine receptors (52). In myeloid cells, $\mathrm{PI} 3 \mathrm{~K} \gamma$ is important both for the recruitment of monocytes/macrophages and neutrophils (53), and for the resolution of inflammation, in particular with macrophages phagocyting apoptotic neutrophils. In macrophages, the dominant role of PI3K $\gamma$ is the resolution of inflammation and immunosuppression (54). Under these conditions, specific inhibitors of PI3K $\gamma(55,56)$ could obviously be of major interest in combined anti-tumoral therapies.

Note that a recent study has evidenced the role of the scavenger receptor clever-1 in TAM pro-tumoral activities. In mouse tumor models, clever-1 blockade leads to macrophage repolarization that become immunostimulatory enhancing $\mathrm{T}$ cell responses against tumors (57). A phase I clinical trial with a blocking anti-clever-1 antibody is currently ongoing in various solid tumors (NCT03733990).

\section{Activation of Anti-tumoral TAM Activities}

We would like to shed light on two main pathways promoting an anti-tumoral TAM activity. One involves the $\mathrm{CD} 40$ pathway, the other one the induction of type I IFN.

The CD40L-CD40 pathway may be activated by CD40 agonists or with cells that express CD40L as it is the case with activated TIL or NKT (58). In a mouse model of pancreatic cancer, the density of the ECM was shown to be reduced after an anti-CD40 agonist treatment, through the activation of matrix metalloproteinases production by TAM, which may facilitate the motility of $\mathrm{T}$ cells (59). Further work from the same group indicates that a CD40 agonist triggers the release of IFN $\gamma$ and CCL2 responsible for both the recruitment of monocytes/macrophages into the tumor and their polarization toward ECM-degrading cells (60).

Even if anti-CD40 antibodies may not only target TAM and DCs, but also other CD40-expressing cells such as endothelial cells, in combination with gemcitabine, CD40 agonists have already been shown to induce clinical responses in patients with surgically incurable pancreatic cancer (59). This CD40dependent TAM activation is more efficient when combined with T cell activation (61), or with TLR9 stimulation (62).

Type I IFN has also been shown to enhance anti-tumor activities of myeloid cells. The release of IFN $\alpha / \beta$ in tumors can be achieved by irradiation (63), some chemotherapeutic agents (64) but more efficiently by a direct activation of the STING (Stimulator of Interferon Genes) molecule. TLR ligands, such as $\mathrm{CpG}$, may also result in the production of IFN $\alpha / \beta$ by TAM. We have recently shown that this type I IFN contribution to anti-tumoral treatments may be strongly inhibited by TGF $\beta$ that accumulates abundantly in spontaneous tumors (48). TGF $\beta$ inhibition may therefore be an important element of an efficient combined treatment stimulating anti-tumor activity of TAM.
Overall, the balance toward anti-tumor activity of TAM maybe switched $\mathrm{ON}$ if one aims at inhibiting their pro-tissular activity while favoring their pro-immune activity. Various clinical trials are ongoing with such macrophages targeting agents (65).

The duration of an increased anti-tumoral activity of TAM is a question that warrants further investigations. Recruited macrophages with high cytotoxic and phagocytic activities were found to accumulate between 4 and 8 days following treatments $(30,33,66)$. Thereafter, factors of the tumor microenvironment, such as VEGF, have been shown to influence the reconstitution of the TAM compartment (30), and to promote tumor outgrowth. The persistence of anti-tumor activity of macrophages may also depend on their interactions with anti-tumor T cells as will be discussed below.

\section{ACTIVATED TAM COOPERATE WITH TIL FOR A GLOBAL ANTI-TUMORAL ACTIVITY}

An increasing number of reports lead to the conclusion that $\mathrm{T}$ cells and TAM can cooperate to fight tumors. We have shown that activated TAM were necessary to reject transplanted tumors after therapeutic vaccination (66) or STING/type I IFN activation (33). Importantly, STING exerts an anti-tumoral activity involving both TAM and T cells $(33,48)$ with a key role exerted by IFN $\alpha / \beta$ production by TAM. In such an acute inflammatory context, the depletion of TAM drastically reduced the production of T-cell chemoattractants and the accumulation of CD8 T cells in tumors. Thus, TAM can either favor or prevent intra-tumoral $\mathrm{T}$ cell infiltration, depending on whether an inflammatory/immune response has been triggered or not. In addition, a positive feed-back may be observed, with $\mathrm{T}$ cells amplifying the activity of immunostimulatory TAM (66). This demonstrates that TAM and anti-tumoral CD8 TIL can work in synergy to reject tumors following an appropriate stimulation.

As a matter of fact, TAM-T cells positive interactions have been observed in various settings, but were rarely put at the forefront. Such positive interactions have been reported after intratumoral injection of TLR3 or TLR9 agonists $(67,68)$, after the use of checkpoints blockers anti-PD1/anti-CTLA4 (69), or after the adoptive transfer of tumor-infiltrating T cells (70) as well as chimeric antigen receptor (CAR) T cells (71). Table 1 summarizes clinical trials in which a combination of drugs targeting TAM and TIL has been evaluated.

\section{Consequences of TAM-T Cell Cooperation}

After facilitating the entry of $\mathrm{T}$ cells in sensitized tumors, TAM can interact closely with T cells as illustrated in Figure 2B and present tumor antigens, and thus reactivate them (72). The importance of such a reactivation may be illustrated by the fact that MHC class I expression on tumor infiltrating myeloid cells is strikingly crucial for the rejection of B16 tumor cells by adoptively transferred tumor-specific CD8 T cells (73).

Thus, TAM may help $\mathrm{T}$ cells, but reciprocally, $\mathrm{T}$ cells can contribute to macrophage activation, and the release of IFN $\gamma$ 
TABLE 1 | Ongoing clinical trials targeting TAM and TIL in solid tumors

\begin{tabular}{|c|c|c|c|c|c|c|c|}
\hline & $\begin{array}{l}\text { Macrophage/TIL } \\
\text { targets }\end{array}$ & $\begin{array}{l}\text { Clinical trial } \\
\text { number }\end{array}$ & Investigators & Indications & Study design & Immune response evaluation & Phase \\
\hline \multirow[t]{4}{*}{$\begin{array}{l}\text { Depletion of } \\
\text { pro-tumoral TAM }\end{array}$} & $\begin{array}{l}\text { Anti- } \\
\text { CCR2/CCR5/anti-PD1 }\end{array}$ & NCT03184870 & Bristol-Myers Squibb & Solid tumors & $\begin{array}{l}\text { aCCR2/CCR5 vs. aCCR2/CCR5 + aPD1 vs. } \\
\text { aCCR2/CCR5+ chemotherapies }\end{array}$ & $\begin{array}{l}\text { Decrease in regulatory } T \text { cells \& } \\
\text { tumor-associated macrophages }\end{array}$ & I \\
\hline & Anti-CFS1R/anti-PD1 & NCT02526017 & $\begin{array}{l}\text { Five Prime } \\
\text { Therapeutics, Inc. }\end{array}$ & Solid tumors & aCSF1R + aPD1 vs. aCSF1R alone & $\begin{array}{l}\text { Changes in macrophage and T-cell } \\
\text { levels/Changes in gene expression in peripheral } \\
\text { T-cell and other leukocyte phenotypes, and } \\
\text { levels of peripheral myeloid-derived suppressor } \\
\text { cells }\end{array}$ & I \\
\hline & $\begin{array}{l}\text { Anti-CFS1R/anti- } \\
\text { PDL1 }\end{array}$ & NCT03238027 & $\begin{array}{l}\text { Syndax } \\
\text { Pharmaceuticals, Inc. }\end{array}$ & Solid tumors & aCSF1R alone vs. aCSF1R + aPDL1 & Inflammatory cytokines/TIL expansion & I \\
\hline & $\begin{array}{l}\text { Anti-CSF1R/anti- } \\
\text { PDL1 }\end{array}$ & NCT02323191 & Hoffmann-La Roche & Solid tumors & $\mathrm{aCSF} 1 \mathrm{R}+\mathrm{aPDL} 1$ & TAM depletion & $I+\|$ \\
\hline \multirow{5}{*}{$\begin{array}{l}\text { Inhibition of } \\
\text { pro-tumoral TAM } \\
\text { activity }\end{array}$} & $\begin{array}{l}\text { Anti-CTLA-4, } \\
\text { Anti-PDL1/OX4OL Ig }\end{array}$ & NTC02705482 & Medlmmune LLC & $\begin{array}{l}\text { Advanced solid } \\
\text { tumors }\end{array}$ & OX40L Ig + aPDL1 vs. OX40L Ig + aCTLA4 & TIL expansion & 1 \\
\hline & Anti-PDL1/OX40L Ig & NTC02221960 & Medlmmune LLC & $\begin{array}{l}\text { Recurrent or } \\
\text { Metastatic Solid } \\
\text { Tumors }\end{array}$ & OX40LIg alone vs. OX40L Ig + aPDL1 & Biomarkers activity on TIL & । \\
\hline & PD1-FC-OX40L & NTC03894618 & Shattuck Labs & $\begin{array}{l}\text { Solid tumors and } \\
\text { lymphomas }\end{array}$ & 1 or 2 inejctions i.t & & । \\
\hline & $\begin{array}{l}\text { TGFbRI } \\
\text { inhibitor/anti-PDL1 }\end{array}$ & NCT02937272 & Eli Lilly and Company & Solid tumors & $\begin{array}{l}\text { TGFbRI inh orally alone vs. TGFbRI inh orally }+ \\
\text { anti-PDL1 i.v }\end{array}$ & & । \\
\hline & $\begin{array}{l}\text { TGFb } \\
\text { inhibitor/anti-PD1 }\end{array}$ & NCT02423343 & Eli Lilly and Company & $\begin{array}{l}\text { Solid tumors } \\
\text { (NLSC/HCC) }\end{array}$ & TGFB inh orally + anti-PD1 i.v & & $I+\|$ \\
\hline \multirow{9}{*}{$\begin{array}{l}\text { Activation of } \\
\text { anti-tumoral TAM } \\
\text { activity }\end{array}$} & $\begin{array}{l}\text { TLR7, } 8 \\
\text { agonist/anti-PDL1 }\end{array}$ & NTC02556463 & Medlmmune LLC & Solid tumors & aTLR7/8 alone vs. aTLR7/8 + aPDL1 & TIL expansion/Inflammatory cytokine levels & । \\
\hline & $\begin{array}{l}\text { TRL9 agonist/OX40 } \\
\text { agonist }\end{array}$ & NCT03831295 & $\begin{array}{l}\text { Stanford Cancer } \\
\text { Institute Palo Alto }\end{array}$ & Solid neoplasms & $\begin{array}{l}\text { TLR9 agonist } \times 3 \text { i.t }+ \text { OX40 agonist } \times 2 \text { i.v and } \\
\times 3 \text { i.t vs. TLR9 agonist } \times 3 \text { i.t }+O \times 40 \text { agonist } \times 3 \\
\text { i.v and } \times 3 \text { i.t }\end{array}$ & & । \\
\hline & $\begin{array}{l}\text { TLR4 } \\
\text { agonist/anti-PD1, } \\
\text { ICOS agonist, OX40 } \\
\text { agonist }\end{array}$ & NCT03447314 & GlaxoSmithKline & Neoplasms & $\begin{array}{l}\text { OX40 + TLR4 agonists vs. ICOS + TLR4 } \\
\text { agonists vs. aPD1 + TRL4 agonists vs. OX40 + } \\
\text { ICOS + TLR4 agonists }\end{array}$ & & । \\
\hline & $\begin{array}{l}\text { STING } \\
\text { agonist/anti-PD1 }\end{array}$ & NCT03172936 & $\begin{array}{l}\text { Novartis } \\
\text { Pharmaceuticals }\end{array}$ & $\begin{array}{l}\text { Solid tumors and } \\
\text { lymphomas }\end{array}$ & $\begin{array}{l}\text { One vs. } 3 \text { doses of STING agonist (i.t) + } 1 \\
\text { injection of anti-PD1 (i.v) }\end{array}$ & $\begin{array}{l}\text { Cytokines, TIL expansion in targeted and } \\
\text { non-targeted lesions }\end{array}$ & । \\
\hline & $\begin{array}{l}\text { STING } \\
\text { agonist/anti-CTLA4 }\end{array}$ & NCT02675439 & $\begin{array}{l}\text { Novartis } \\
\text { Pharmaceuticals }\end{array}$ & $\begin{array}{l}\text { Solid tumors and } \\
\text { lymphomas }\end{array}$ & $\begin{array}{l}3 \text { injections of STING agonist (i.t) vs. } 2 \text { injections } \\
\text { of STING agonist (i.t) }+1 \text { injection of aCTLA4 }\end{array}$ & $\begin{array}{l}\text { Measurement of CD8-TIL counts/RNA } \\
\text { expression analysis of IFN gamma and } \\
\text { immunomodulatory genes }\end{array}$ & । \\
\hline & $\begin{array}{l}\text { CD40 } \\
\text { agonist/anti-PDL1 }\end{array}$ & NCT02304393 & Hoffmann-La Roche & $\begin{array}{l}\text { Advanced/ } \\
\text { metastatic solid } \\
\text { tumors }\end{array}$ & $\begin{array}{l}1 \text { dose of } \mathrm{CD} 40 \text { agonist i.v }+ \text { aPDL1 vs. } 1 \text { dose } \\
\text { of } C D 40 \text { agonist s.c }+ \text { aPDL1 }\end{array}$ & $\begin{array}{l}\text { TIL expansion, PDL1 expression on tumor and } \\
\text { immune infiltrating cells }\end{array}$ & । \\
\hline & $\begin{array}{l}\text { anti-CD47, } \\
\text { IFN- } \alpha 2 / \text { anti-PD1, } \\
\text { anti-PDL1 }\end{array}$ & NCT02890368 & $\begin{array}{l}\text { Trillium Therapeutics } \\
\text { Inc. }\end{array}$ & Solid tumors & $\begin{array}{l}\text { aCD } 47 \text { Monotherapy/aCD47 + PD-1/PD-L1 } \\
\text { Inhibitor/aCD47 + pegylated IFN- } \alpha 2 / a C D 47+ \\
\text { T-Vec/aCD47 + radiation }\end{array}$ & Anti-tumor activity & । \\
\hline & $\begin{array}{l}\text { GMCSF/iNeo-Vac- } \\
\text { P01 } \\
\text { (peptides) }\end{array}$ & NCT03662815 & $\begin{array}{l}\text { Sir Run Run Shaw } \\
\text { Hospital }\end{array}$ & Solid tumors & iNeo-Vac-P01 (peptides)+ GM-CSF x7 doses & $\begin{array}{l}\text { IFN-gamma measurement/CD4 and CD8 T } \\
\text { cells subsets }\end{array}$ & । \\
\hline & $\begin{array}{l}\text { Ad-IFN } \gamma / \text { TIL adoptive } \\
\text { transfer }\end{array}$ & NCT01082887 & $\begin{array}{l}\text { Nantes University } \\
\text { Hospital }\end{array}$ & $\begin{array}{l}\text { Metastatic } \\
\text { melanoma }\end{array}$ & $\begin{array}{l}2 \text { injections of Ad-IFNy (i.t) }+2 \text { injections of TIL } \\
\text { (i.v) }\end{array}$ & & $1+\|$ \\
\hline
\end{tabular}


seems determinant in this process (66). For instance, the antitumor potency of some adoptively transferred $\mathrm{T}$ cells was shown to rely on the IFN $\gamma$-dependent activation of TAM (74).

Another consequence of such a TAM repolarization is the acquisition of effector functions by these activated cells. Indeed, appropriately activated TAM can phagocyte and engulf tumor cells $(75,76)$. Additionally, they can kill tumor cells, as shown by several groups $(67,68)$, including ours $(66)$. TAM, endowed with cytotoxic and cytostatic activities, can kill malignant cells by TNF $\alpha$ secretion $(66,77)$, NO (74) and sometimes on TRAIL (78).

\section{CONCLUSION}

The common point of view that TAM are pro-tumoral cells is only correct in one specific situation: that of growing tumors. We have recalled that TAM could play such a role in different ways, including by trapping $\mathrm{T}$ cells in the tumor stroma and by reducing their mobility and therefore their capacity to reach cancer cells.

However, we have also discussed that TAM, when appropriately stimulated, have the capacity to cooperate with $\mathrm{T}$ cells for an anti-tumoral action. Despite the well-established importance of such a cooperation in anti-infectious immune responses, its importance in anti-tumoral responses has been too often neglected. First, 30 years ago, it has been neglected by those who attempted to treat cancer by only stimulating the innate immune system. More recently, the importance of the TAM-T cell cooperation has again been ignored by those who considered that, for anti-tumoral immune responses, $\mathrm{T}$ cells were the good guys and macrophages the bad ones.

We have shown here that an efficient strategy should aim at stimulating both $\mathrm{T}$ cells and TAM so as to promote their cooperation. This cooperation is not just about a help provided by TAM to T cells: the two cell types may be both helpers

\section{REFERENCES}

1. Wynn TA, Chawla A, Pollard JW. Macrophage biology in development, homeostasis and disease. Nature. (2013) 496:445-55. doi: $10.1038 /$ nature12034

2. Biswas SK, Mantovani A. Macrophage plasticity and interaction with lymphocyte subsets: cancer as a paradigm. Nat Immunol. (2010) 11:889-96. doi: $10.1038 /$ ni. 1937

3. Sagoo P, Garcia Z, Breart B, Lemaitre F, Michonneau D, Albert ML, et al. In vivo imaging of inflammasome activation reveals a subcapsular macrophage burst response that mobilizes innate and adaptive immunity. Nat Med. (2016) 22:64-71. doi: 10.1038/nm.4016

4. Guerriero JL. Macrophages: the road less traveled, changing anticancer therapy. Trends Mol Med. (2018) 24:472-89. doi: 10.1016/j.molmed.2018.03.006

5. DeNardo DG, Ruffell B. Macrophages as regulators of tumour immunity and immunotherapy. Nat Rev Immunol. (2019) 19:369-82. doi: 10.1038/s41577-019-0127-6

6. Peranzoni E, Lemoine J, Vimeux L, Feuillet V, Barrin S, Kantari-Mimoun $\mathrm{C}$, et al. Macrophages impede CD8 T cells from reaching tumor cells and limit the efficacy of anti-PD-1 treatment. Proc Natl Acad Sci USA. (2018) 115:E4041-E50. doi: 10.1073/pnas.1720948115

7. Beatty GL, Winograd R, Evans RA, Long KB, Luque SL, Lee JW, et al. Exclusion of $\mathrm{T}$ cells from pancreatic carcinomas in mice for the other, and final effectors against the tumor. Treatments aiming at stimulating only one cell type (only $\mathrm{T}$ cells or only macrophages) should be systematically replaced by well-thought combined treatments for stimulating both of them. In particular, $T$ cell-focused treatments with checkpoint inhibitors or CAR T cells would greatly benefit being combined with activators of proimmune TAM activities such as CD40 agonists, STING activators or otherof IFN $\alpha$ inducers, and with inhibitors of pro-tissular TAM functions, i.e., inhibitors ofTGF $\beta$ or class IIa HDAC. The only caveat we would put on it is the potential immune-related adverse effects that may follow efficient tumor rejection. But taking into account that such triple combinations have the greatest chances to promote efficient anti-tumoral therapies would be a fundamental step forward.

\section{AUTHOR CONTRIBUTIONS}

ED, AT, and NB conceived the article, wrote the first version of the manuscript, and integrated inputs from MG. MG designed the Table 1 with the contribution of NB and the Figure 1 with the contribution of AT. ED and AT designed the Figure 2. All authors approved the final version of the article.

\section{ACKNOWLEDGMENTS}

This work was granted by Worldwide Cancer Research, the Plan Cancer (Tumor Heterogeneity and Ecosystem Program), the Comité de Paris de La Ligue Contre le Cancer, the Cancer Research for Personalized Medicine (CARPEM), CNRS, INSERM, and University Paris-Descartes. MG was granted by the Ministère de l'Education Nationale, de l'Enseignement Supérieur et de la Recherche. We are grateful to E. Peranzoni and IMAG'IC facility of the Cochin Institute for the Figure 2. is regulated by $\mathrm{Ly} 6 \mathrm{C}(\mathrm{low}) \mathrm{F} 4 / 80(+)$ extratumoral macrophages. Gastroenterology. (2015) 149:201-10. doi: 10.1053/j.gastro.2015. 04.010

8. Audemard-Verger A, Riviere M, Durand A, Peranzoni E, Guichard V, Hamon $\mathrm{P}$, et al. Macrophages induce long-term trapping of gammadelta $\mathrm{T}$ cells with innate-like properties within secondary lymphoid organs in the steady state. $J$ Immunol. (2017) 199:1998-2007. doi: 10.4049/jimmunol.1700430

9. Engelhardt JJ, Boldajipour B, Beemiller P, Pandurangi P, Sorensen C, Werb $\mathrm{Z}$, et al. Marginating dendritic cells of the tumor microenvironment crosspresent tumor antigens and stably engage tumor-specific T cells. Cancer Cell. (2012) 21:402-17. doi: 10.1016/j.ccr.2012.01.008

10. Krummel MF, Bartumeus F, Gerard A. T cell migration, search strategies and mechanisms. Nat Rev Immunol. (2016) 16:193-201. doi: 10.1038/nri.2015.16

11. Salmon H, Franciszkiewicz K, Damotte D, Dieu-Nosjean MC, Validire P, Trautmann A, et al. Matrix architecture defines the preferential localization and migration of $\mathrm{T}$ cells into the stroma of human lung tumors. J Clin Investigat. (2012) 122:899-910. doi: 10.1172/JCI45817

12. Molon B, Ugel S, Del Pozzo F, Soldani C, Zilio S, Avella D, et al. Chemokine nitration prevents intratumoral infiltration of antigen-specific T cells. J Exp Med. (2011) 208:1949-62. doi: 10.1084/jem.20101956

13. Peranzoni E, Rivas-Caicedo A, Bougherara H, Salmon H, Donnadieu E. Positive and negative influence of the matrix architecture on antitumor immune surveillance. Cell Mol Life Sci. (2013) 70:4431-48. doi: $10.1007 / \mathrm{s} 00018-013-1339-8$ 
14. Ingman WV, Wyckoff J, Gouon-Evans V, Condeelis J, Pollard JW. Macrophages promote collagen fibrillogenesis around terminal end buds of the developing mammary gland. Dev Dyn. (2006) 235:3222-9. doi: $10.1002 /$ dvdy.20972

15. Wynn TA, Vannella KM. Macrophages in tissue repair, regeneration, and fibrosis. Immunity. (2016) 44:450-62. doi: 10.1016/j.immuni.2016.02.015

16. Becht E, de Reynies A, Giraldo NA, Pilati C, Buttard B, Lacroix L, et al. Immune and stromal classification of colorectal cancer is associated with molecular subtypes and relevant for precision immunotherapy. Clin Cancer Res. (2016) 22:4057-66. doi: 10.1158/1078-0432.CCR-15-2879

17. Calon A, Lonardo E, Berenguer-Llergo A, Espinet E, Hernando-Momblona X, Iglesias $\mathrm{M}$, et al. Stromal gene expression defines poor-prognosis subtypes in colorectal cancer. Nat Genet. (2015) 47:320-9. doi: 10.1038/ng.3225

18. Hugo W, Zaretsky JM, Sun L, Song C, Moreno BH, Hu-Lieskovan S, et al. Genomic and transcriptomic features of response to anti-PD-1 therapy in metastatic melanoma. Cell. (2016) 165:35-44. doi: 10.1016/j.cell.2016.02.065

19. Afik R, Zigmond E, Vugman M, Klepfish M, Shimshoni E, Pasmanik-Chor $\mathrm{M}$, et al. Tumor macrophages are pivotal constructors of tumor collagenous matrix. J Exp Med. (2016) 213:2315-31. doi: 10.1084/jem.20151193

20. Zhu Y, Herndon JM, Sojka DK, Kim KW, Knolhoff BL, Zuo C, et al. Tissueresident macrophages in pancreatic ductal adenocarcinoma originate from embryonic hematopoiesis and promote tumor progression. Immunity. (2017) 47:323-38 e6. doi: 10.1016/j.immuni.2017.07.014

21. Quaranta V, Rainer C, Nielsen SR, Raymant ML, Ahmed MS, Engle DD, et al. Macrophage-derived granulin drives resistance to immune checkpoint inhibition in metastatic pancreatic cancer. Cancer Res. (2018) 78:4253-69. doi: 10.1158/0008-5472.CAN-17-3876

22. DeNardo DG, Brennan DJ, Rexhepaj E, Ruffell B, Shiao SL, Madden $\mathrm{SF}$, et al. Leukocyte complexity predicts breast cancer survival and functionally regulates response to chemotherapy. Cancer Discov. (2011) 1:5467. doi: 10.1158/2159-8274.CD-10-0028

23. Mok S, Koya RC, Tsui C, Xu J, Robert L, Wu L, et al. Inhibition of CSF-1 receptor improves the antitumor efficacy of adoptive cell transfer immunotherapy. Cancer Res. (2014) 74:153-61. doi: 10.1158/0008-5472.CAN-13-1816

24. Neubert NJ, Schmittnaegel M, Bordry N, Nassiri S, Wald N, Martignier C, et al. T cell-induced CSF1 promotes melanoma resistance to PD1 blockade. Sci Transl Med. (2018) 10:436. doi: 10.1126/scitranslmed.aan3311

25. Strachan DC, Ruffell B, Oei Y, Bissell MJ, Coussens LM, Pryer N, et al. CSF1R inhibition delays cervical and mammary tumor growth in murine models by attenuating the turnover of tumor-associated macrophages and enhancing infiltration by CD8+ T cells. Oncoimmunology. (2013) 2:e26968. doi: 10.4161 /onci.26968

26. Zhu Y, Knolhoff BL, Meyer MA, Nywening TM, West BL, Luo J, et al. CSF1/CSF1R blockade reprograms tumor-infiltrating macrophages and improves response to T-cell checkpoint immunotherapy in pancreatic cancer models. Cancer Res. (2014) 74:5057-69. doi: 10.1158/0008-5472.CAN-13-3723

27. Mantovani A, Marchesi F, Malesci A, Laghi L, Allavena P. Tumour-associated macrophages as treatment targets in oncology. Nat Rev Clin Oncol. (2017) 14:399-416. doi: 10.1038/nrclinonc.2016.217

28. Cannarile MA, Weisser M, Jacob W, Jegg AM, Ries CH, Ruttinger D. Colony-stimulating factor 1 receptor (CSF1R) inhibitors in cancer therapy. J Immunother Cancer. (2017) 5:53. doi: 10.1186/s40425-017-0257-y

29. Nywening TM, Wang-Gillam A, Sanford DE, Belt BA, Panni RZ, Cusworth $\mathrm{BM}$, et al. Targeting tumour-associated macrophages with CCR2 inhibition in combination with FOLFIRINOX in patients with borderline resectable and locally advanced pancreatic cancer: a single-centre, open-label, dosefinding, non-randomised, phase $1 \mathrm{~b}$ trial. Lancet Oncol. (2016) 17:651-62. doi: 10.1016/S1470-2045(16)00078-4

30. Loyher PL, Hamon P, Laviron M, Meghraoui-Kheddar A, Goncalves E, Deng $Z$, et al. Macrophages of distinct origins contribute to tumor development in the lung. J Exp Med. (2018) 215:2536-53. doi: 10.1084/jem.20180534

31. Suzuki E, Kapoor V, Jassar AS, Kaiser LR, Albelda SM. Gemcitabine selectively eliminates splenic Gr-1+/CD11b + myeloid suppressor cells in tumor-bearing animals and enhances antitumor immune activity. Clin Cancer Res. (2005) 11:6713-21. doi: 10.1158/1078-0432.CCR05-0883
32. Allavena P, Signorelli M, Chieppa M, Erba E, Bianchi G, Marchesi F, et al. Antiinflammatory properties of the novel antitumor agent yondelis (trabectedin): inhibition of macrophage differentiation and cytokine production. Cancer Res. (2005) 65:2964-71. doi: 10.1158/0008-5472.CAN-04-4037

33. Weiss JM, Guerin MV, Regnier F, Renault G, Galy-Fauroux I, Vimeux L, et al. The STING agonist DMXAA triggers a cooperation between T lymphocytes and myeloid cells that leads to tumor regression. Oncoimmunology. (2017) 6:e1346765. doi: 10.1080/2162402X.2017.1346765

34. Ganss R, Ryschich E, Klar E, Arnold B, Hammerling GJ. Combination of Tcell therapy and trigger of inflammation induces remodeling of the vasculature and tumor eradication. Cancer Res. (2002) 62:1462-70.

35. Sektioglu IM, Carretero R, Bender N, Bogdan C, Garbi N, Umansky V, et al. Macrophage-derived nitric oxide initiates T-cell diapedesis and tumor rejection. Oncoimmunology. (2016) 5:e1204506. doi: 10.1080/2162402X.2016.1204506

36. Long KB, Beatty GL. Harnessing the antitumor potential of macrophages for cancer immunotherapy. Oncoimmunology. (2013) 2:e26860. doi: $10.4161 /$ onci.26860

37. Fridman WH, Zitvogel L, Sautes-Fridman C, Kroemer G. The immune contexture in cancer prognosis and treatment. Nat Rev Clin Oncol. (2017) 14:717-34. doi: 10.1038/nrclinonc.2017.101

38. Pages F, Lebel-Binay S, Vieillefond A, Deneux L, Cambillau M, Soubrane O, et al. Local immunostimulation induced by intravesical administration of autologous interferon-gamma-activated macrophages in patients with superficial bladder cancer. Clin Exp Immunol. (2002) 127:303-9. doi: 10.1046/j.1365-2249.2002.01766.x

39. Axelrod RS, Havas HF, Murasko DM, Bushnell B, Guan CF. Effect of the mixed bacterial vaccine on the immune response of patients with non-small cell lung cancer and refractory malignancies. Cancer. (1988) 61:2219-30.

40. Engelhardt R, Mackensen A, Galanos C. Phase I trial of intravenously administered endotoxin (Salmonella abortus equi) in cancer patients. Cancer Res. (1991) 51:2524-30.

41. Klimp AH, de Vries EG, Scherphof GL, Daemen T. A potential role of macrophage activation in the treatment of cancer. Crit Rev Oncol. (2002) 44:143-61. doi: 10.1016/S1040-8428(01)00203-7

42. Nardin A, Lefebvre ML, Labroquere K, Faure O, Abastado JP. Liposomal muramyl tripeptide phosphatidylethanolamine: targeting and activating macrophages for adjuvant treatment of osteosarcoma. Curr Cancer Drug Targets. (2006) 6:123-33. doi: 10.2174/156800906776056473

43. Tang ZY, Zhou HY, Zhao G, Chai LM, Zhou M, Lu JZ, et al. Preliminary result of mixed bacterial vaccine as adjuvant treatment of hepatocellular carcinoma. Med Oncol Tumor Pharmacother. (1991) 8:23-8.

44. Suragani RN, Cadena SM, Cawley SM, Sako D, Mitchell D, Li R, et al. Transforming growth factor-beta superfamily ligand trap ACE-536 corrects anemia by promoting late-stage erythropoiesis. Nat Med. (2014) 20:408-14. doi: $10.1038 / \mathrm{nm} .3512$

45. Farzaneh M, Derakhshan Z, Hallajzadeh J, Sarani NH, Nejabatdoust A, Khoshnam SE. Suppression of TGF-beta and ERK signaling pathways as a new strategy to provide rodent and non-rodent pluripotent stem cells. Curr Stem Cell Res Ther. (2019) 14:466-73. doi: 10.2174/1871527318666190314110529

46. Mariathasan S, Turley SJ, Nickles D, Castiglioni A, Yuen K, Wang Y, et al. TGFbeta attenuates tumour response to PD-L1 blockade by contributing to exclusion of T cells. Nature. (2018) 554:544-8. doi: 10.1038/nature25501

47. Tauriello DVF, Palomo-Ponce S, Stork D, Berenguer-Llergo A, BadiaRamentol J, Iglesias $\mathrm{M}$, et al. TGFbeta drives immune evasion in genetically reconstituted colon cancer metastasis. Nature. (2018) 554:538-43. doi: $10.1038 /$ nature 25492

48. Guerin M, Regnier F, Feuillet V, Vimeux L, Weiss JM, Guilbert T, et al. TGFbeta blocks STING-induced IFN release and tumor rejection in spontaneous mammary tumors. BioRxiv. (2018). doi: 10.1101/336990

49. Guerriero JL, Sotayo A, Ponichtera HE, Castrillon JA, Pourzia AL, Schad S, et al. Class IIa HDAC inhibition reduces breast tumours and metastases through anti-tumour macrophages. Nature. (2017) 543:428-32. doi: 10.1038/nature21409

50. Glenisson W, Castronovo V, Waltregny D. Histone deacetylase 4 is required for TGFbeta1-induced myofibroblastic differentiation. Biochim Biophys Acta. (2007) 1773:1572-82. doi: 10.1016/j.bbamcr.2007. 05.016 
51. Guo W, Saito S, Sanchez CG, Zhuang Y, Gongora Rosero RE, Shan B, et al. TGF-betal stimulates HDAC4 nucleus-to-cytoplasm translocation and NADPH oxidase 4-derived reactive oxygen species in normal human lung fibroblasts. Am J Physiol Lung Cell Mol Physiol. (2017) 312:L936-L44. doi: 10.1152/ajplung.00256.2016

52. Solinas G, Becattini B. The role of PI3Kgamma in metabolism and macrophage activation. Oncotarget. (2017) 8:106145-6. doi: 10.18632/oncotarget.22068

53. Hirsch E, Katanaev VL, Garlanda C, Azzolino O, Pirola L, Silengo $\mathrm{L}$, et al. Central role for $\mathrm{G}$ protein-coupled phosphoinositide 3kinase gamma in inflammation. Science. (2000) 287:1049-53. doi: 10.1126/science.287.5455.1049

54. Kaneda MM, Messer KS, Ralainirina N, Li H, Leem CJ, Gorjestani S, et al. PI3Kgamma is a molecular switch that controls immune suppression. Nature. (2016) 539:437-42. doi: 10.1038/nature19834

55. Evans CA, Liu T, Lescarbeau A, Nair SJ, Grenier L, Pradeilles JA, et al. Discovery of a selective phosphoinositide-3-kinase (PI3K)-gamma inhibitor (IPI-549) as an immuno-oncology clinical candidate. ACS Med Chem Lett. (2016) 7:862-7. doi: 10.1021/acsmedchemlett.6b00238

56. Pemberton N, Mogemark M, Arlbrandt S, Bold P, Cox RJ, Gardelli C, et al. Discovery of highly isoform selective orally bioavailable phosphoinositide 3-kinase (PI3K)-gamma inhibitors. J Med Chem. (2018) 61:5435-41. doi: 10.1021 /acs.jmedchem.8b00447

57. Viitala M, Virtakoivu R, Tadayon S, Rannikko J, Jalkanen S, Hollmen M. Immunotherapeutic blockade of macrophage clever- 1 reactivates the CD8(+) T-cell response against immunosuppressive tumors. Clin Cancer Res. (2019) 25:3289-303. doi: 10.1158/1078-0432.CCR-18-3016

58. Cortesi F, Delfanti G, Grilli A, Calcinotto A, Gorini F, Pucci F, et al. Bimodal CD40/Fas-dependent crosstalk between iNKT cells and tumor-associated macrophages impairs prostate cancer progression. Cell Rep. (2018) 22:300620. doi: 10.1016/j.celrep.2018.02.058

59. Beatty GL, Chiorean EG, Fishman MP, Saboury B, Teitelbaum UR, Sun W, et al. CD40 agonists alter tumor stroma and show efficacy against pancreatic carcinoma in mice and humans. Science. (2011) 331:1612-6. doi: 10.1126/science. 1198443

60. Long KB, Gladney WL, Tooker GM, Graham K, Fraietta JA, Beatty GL. IFNgamma and CCL2 cooperate to redirect tumor-infiltrating monocytes to degrade fibrosis and enhance chemotherapy efficacy in pancreatic carcinoma. Cancer Discov. (2016) 6:400-13. doi: 10.1158/2159-8290.CD-15-1032

61. Jackaman C, Lew AM, Zhan Y, Allan JE, Koloska B, Graham PT, et al. Deliberately provoking local inflammation drives tumors to become their own protective vaccine site. Int Immunol. (2008) 20:1467-79. doi: 10.1093/intimm/dxn104

62. Jensen JL, Rakhmilevich A, Heninger E, Broman AT, Hope C, Phan F, et al. Tumoricidal effects of macrophage-activating immunotherapy in a murine model of relapsed/refractory multiple myeloma. Cancer Immunol Res. (2015) 3:881-90. doi: 10.1158/2326-6066.CIR-15-0025-T

63. Vanpouille-Box C, Demaria S, Formenti SC, Galluzzi L. Cytosolic DNA sensing in organismal tumor control. Cancer Cell. (2018) 34:361-78. doi: 10.1016/j.ccell.2018.05.013

64. Sistigu A, Yamazaki T, Vacchelli E, Chaba K, Enot DP, Adam J, et al. Cancer cell-autonomous contribution of type I interferon signaling to the efficacy of chemotherapy. Nat Med. (2014) 20:1301-9. doi: 10.1038/nm.3708

65. Pathria P, Louis TL, Varner JA. Targeting tumor-associated macrophages in cancer. Trends Immunol. (2019) 40:310-27. doi: 10.1016/j.it.2019.02.003

66. Thoreau M, Penny HL, Tan K, Regnier F, Weiss JM, Lee B, et al. Vaccineinduced tumor regression requires a dynamic cooperation between $\mathrm{T}$ cells and myeloid cells at the tumor site. Oncotarget. (2015) 6:27832-46. doi: 10.18632/oncotarget.4940
67. Shime H, Matsumoto M, Oshiumi H, Tanaka S, Nakane A, Iwakura Y, et al. Toll-like receptor 3 signaling converts tumor-supporting myeloid cells to tumoricidal effectors. Proc Natl Acad Sci USA. (2012) 109:2066-71. doi: 10.1073/pnas.1113099109

68. Shirota Y, Shirota H, Klinman DM. Intratumoral injection of CpG oligonucleotides induces the differentiation and reduces the immunosuppressive activity of myeloid-derived suppressor cells. J Immunol. (2012) 188:1592-9. doi: 10.4049/jimmunol.1101304

69. Gubin MM, Esaulova E, Ward JP, Malkova ON, Runci D, Wong P, et al. High-dimensional analysis delineates myeloid and lymphoid compartment remodeling during successful immune-checkpoint cancer therapy. Cell. (2018) 175:1443. doi: 10.1016/j.cell.2018.11.003

70. Hollenbaugh JA, Dutton RW. IFN-gamma regulates donor CD8 T cell expansion, migration, and leads to apoptosis of cells of a solid tumor. $J$ Immunol. (2006) 177:3004-11. doi: 10.4049/jimmunol.177.5.3004

71. Textor A, Listopad JJ, Wuhrmann LL, Perez C, Kruschinski A, Chmielewski $\mathrm{M}$, et al. Efficacy of CAR T-cell therapy in large tumors relies upon stromal targeting by IFNgamma. Cancer Res. (2014) 74:6796-805. doi: 10.1158/0008-5472.CAN-14-0079

72. Ma Y, Mattarollo SR, Adjemian S, Yang H, Aymeric L, Hannani D, et al. CCL2/CCR2-dependent recruitment of functional antigen-presenting cells into tumors upon chemotherapy. Cancer Res. (2014) 74:436-45. doi: 10.1158/0008-5472.CAN-13-1265

73. Kerkar SP, Goldszmid RS, Muranski P, Chinnasamy D, Yu Z, Reger RN, et al. IL-12 triggers a programmatic change in dysfunctional myeloidderived cells within mouse tumors. J Clin Investigat. (2011) 121:4746-57. doi: 10.1172/JCI58814

74. Vicetti Miguel RD, Cherpes TL, Watson LJ, McKenna KC. CTL induction of tumoricidal nitric oxide production by intratumoral macrophages is critical for tumor elimination. J Immunol. (2010) 185:6706-18. doi: 10.4049/jimmunol.0903411

75. Bougherara H, Nemati F, Nicolas A, Massonnet G, Pugniere M, Ngo C, et al. The humanized anti-human AMHRII mAb 3C23K exerts an antitumor activity against human ovarian cancer through tumor-associated macrophages. Oncotarget. (2017) 8:99950-65. doi: 10.18632/oncotarget.21556

76. Montalvao F, Garcia Z, Celli S, Breart B, Deguine J, Van Rooijen N, et al. The mechanism of anti-CD20-mediated B cell depletion revealed by intravital imaging. J Clin Investigat. (2013) 123:5098-103. doi: 10.1172/JCI 70972

77. Zhang B, Karrison T, Rowley DA, Schreiber H. IFN-gamma- and TNFdependent bystander eradication of antigen-loss variants in established mouse cancers. J Clin Investigat. (2008) 118:1398-404. doi: 10.1172/JCI 33522

78. Griffith TS, Wiley SR, Kubin MZ, Sedger LM, Maliszewski CR, Fanger NA. Monocyte-mediated tumoricidal activity via the tumor necrosis factor-related cytokine, TRAIL. J Exp Med. (1999) 189:1343-54. doi: 10.1084/jem.189. 8.1343

Conflict of Interest Statement: The authors declare that the research was conducted in the absence of any commercial or financial relationships that could be construed as a potential conflict of interest.

Copyright (C) 2019 Bercovici, Guérin, Trautmann and Donnadieu. This is an openaccess article distributed under the terms of the Creative Commons Attribution License (CC BY). The use, distribution or reproduction in other forums is permitted, provided the original author(s) and the copyright owner(s) are credited and that the original publication in this journal is cited, in accordance with accepted academic practice. No use, distribution or reproduction is permitted which does not comply with these terms. 